\title{
OBITUARIES
}

\section{Mr. J. R. Womersley}

JoHN RONALD Womerscey was born on June 20, 1907, at Morley, in Yorkshire. He studied at the Imperial College of Science and Technology, London, and was awarded a first class in mathematics in 1928. After some further study there he took a post at the Shirley Institute (British Cotton Industry Research Association, Manchester), where he learnt to be a statistician. In 1937 he joined the Scientific Civil Service, moving to the Armament Research Department, Woolwich, and during 1942-45 he was head of the Ministry of Supply Advisory Service on Statistical Methods. At the end of the War the National Physical Laboratory set up its Mathematics Division, and Womersley was appointed to be its first superintendent. This post he held until 1950, when he took up duty as chief mathematician for the British Tabulating Machine Co. at Letchworth. The post came to an end in 1954, and after doing some work for the Medical Research Council he went to America for duties as a mathematician at Wright Field, Dayton, Ohio, under the American Air Force. He underwent a serious operation last year, but made an incomplete recovery and died on March 7 . He leaves a widow and three daughters.

The general impression that Womersley gave was his sense of adventure in all the work he was doing. He was always looking for something new to undertake, sometimes be it said a little at the expense of the actual work in hand. I really only saw the fringe of his work during the War, but he seemed to impart a most refreshing breadth of outlook into what might have been just a dull routine. Thus, the chemists had never succeeded in making their propellants to beyond a certain limit of accuracy which he had evaluated, and there seemed no prospect of improving the manufacture. He was not content to leave the matter at that, but started to study whether the gun that was to use this propellant matched it in accuracy; for it might well be that for some parts of it a useless and expensive excess of accuracy had been demanded.

When the Mathematics Division at Teddington was set up at the end of the War, Womersley was selected from among a strong field to be its first superintendent. The starting of a new institution was exactly the thing he was good at. The general programme for it had, of course, been laid down by the committee which had recommended its establishment, but within these rather broad limits he got it going quite admirably, collecting a strong staff, and giving them the right types of work to do. One of the chief tasks of the Division was to initiate the development of an electronic computing machine. This he named the ACE (for Automatic Computing Engine-the word Engine being borrowed from Babbage's name for it a century before), and he and his staff took an active part in starting it ; and though, of course, the actual construction fell chiefly to the electrical engineers, they were ably assisted in this work by several of his mathematicians. After a few years, however, when the Division was running smoothly, he became restless and accepted the invitation of the Tabulating Machine Co., and there spent some years developing their instruments, including a small electronic computer for business use.
This, too, ultimately did not satisfy him. The post came to an end, and while he was waiting for the position he was going to have in America, he went back to doing mathematics himself, a thing he had scarcely had time for during the years when he had been kept busy supervising the work of others. He made a study of the hydrodynamical problem of the flow of liquid through an elastic tube, with the view of understanding the way that the blood flows in the arteries. He had very good success in this problem, and it is a tribute to his general ability that he could revert to such a different kind of work after so long an interval. In 1955 he took up duty in a responsible post as mathematician at Wright Field, but even then he continued his work on bloodflow, and his last published paper was a report on this subject for the aero-medical branch of the U.S. Air Force.

We must grieve at the loss of a very able man, whose intellectual adventures had already carried him far over the fields available to a mathematician. It is idle now to speculate how much farther he would have gone if he had been granted the normal span of human life.

C. G. DARWIN

\section{Dr. A. F. S. Kent}

Albert Frank Stanley Krint died on March 30. He was born on March 26, 1863, and so was one of the small band of scientists who have lived to more than ninety years of age. He was educated at Magdalen College School and was a member of Magdalen College, Oxford, taking his degree in the Honours School of Natural Science in 1886. He demonstrated in physiology at Owens College and the University of Manchester during 1887-89, in the University of Oxford during 1889-91, and at St. Thomas's Hospital, London, during 1891-95. In 1899 he was appointed the first professor of physiology at University College, Bristol, which became the University of Bristol in 1909.

Stanley Kent is best known for his work on the conduction of the mammalian heart beat, which he commenced under Gotch in Oxford. The atrioventricular bundle was investigated simultaneously by himself and in Leipzig by W. His, publications by both of them appearing in 1893. Although Kent gave his first communication on the subject to the Physiological Society in November 1892, it is clear that both share the credit for the discovery. In a series of communications, Kent described in detail the muscular links between atria and ventricles in mammals and the peculiar histological appearance of the cells found in them. He demonstrated the close anatomical connexion between these cells and the ventricular muscle fibres, and was able to show that atrial contractions can be made to follow artificially induced ventricular beats, though such reversed transmission through the bundle was impossible under strong vagal stimulation. The investigation of the bundle and its properties forms the basis of our knowledge of the normal conduction of the heart beat and of the functional dissociation of ventricles from atria which occurs in heart-block.

In 1914 Kent described also a subsidiary atrioventricular connexion on the right side of the heart, 


\section{No. 4618 May 3, 1958}

the exact functional significance of which is still disputed.

He was elected a member of the Physiological Society in 1887, and since 1952 had been the Society's senior member, succeeding in that capacity another nonagenarian, Sir Charles Sherrington.

Kent's drive and powers of organization were made use of in various ways. He was an early worker on $\mathrm{X}$-rays and helped to develop the Radiological Department at St. Thomas's Hospital towards the end of the pest century. In Bristol he founded and carried on in University College a clinical and bacteriological research laboratory, which later became the City's public health laboratory; he was also for a time bacteriologist to the Royal Infirmary and lectured on this subject in the Medical School. He was one of the leading spirits in the campaign for the formation of a University which started in University College in 1900, and nine years later, owing in no small measure to his enthusiasm, the University was founded. In it he designed a new Department of Physiology, the nucleus of the present Department.

During the First World War, Kent became interested in problems of industrial fatigue and was responsible for various Government publications on the subject. In 1918 he resigned from his chair at Bristol to organize and direct a Department of Industrial Administration at the Manchester Municipal Technical College. After his retirement he returned to live in the West Country, converting one of the rooms in his house into a laboratory, where he eagerly continued his histological work on the heart, and he left behind him several thousands of sections representing the work of many years. His keen interest in physiological matters was retained until within a year or so of his death, when serious ill-heslth overtook him ; this, his practioal wisdom and his friendliness were his most striking characteristics.

\section{R. J. BROCKLEHURST}

\section{Prof. H. S. Langfeld}

Psychologists in Great Britain have reason to be grateful to the late Prof. Herbert Sidney Langfeld for much more than the three highly successful textbooks of which he was an editor. Some will know him as the author of one of the few truly psychological works on æesthetics which was, perhaps, a natural development from his earlier research on vision, bodily movement and synæsthesia and his interest in art-he had a fine collection of woodengravings. Many more owe him a debt for his untiring work during the years he was secretary of the committes under the auspices of which the triennial intermational congresses of psychology are held. None could have filled this office better than $h e$, and although he remained characteristically in the background, his efforts have been an important factor in securing international recognition of psychology as an experimental scientific discipline.

Langfeld was born on July 24, 1879, at Philadelphia, and educated at the Central High School there and at Haverford College. In 1902 he went as a member of the U.S. Diplomatic Service to Berlin, and stayed on there to take his doctorate of philosophy at the University under Carl Stumpf in 1909. He became a member of the staff at Harvard in the following year, and from 1924 to 1947, when he retired, was professor of psychology and director of the Psychological Laboratory at Princeton. He was president of the American Psychological Association
1241

in 1930, editor of the Psychological Review during 1934-47, a fellow of the New York Academy of Sciences, a member of the Pontifical Academy of Sciences, and permanent secretary of the International Congress of Psychology. He died in Princeton on February 25.

Proud of his German degree and of his European contacts, he and his wife were frequent visitors to Great Britain and the Continent, and their genuinely international sympathies brought them a wide circle of friends in many countries. They were generous hosts in their beautiful home on the outskirts of Princeton, where colleagues, graduate students from his department and visitors from overseas could relax.

Only those who have had the good fortune to work in his laboratory can appreciate fully his qualities as a departmental chairman. Jealous for the honour of psychology as a science, for his department and for his distinguished staff, but entirely without selfseeking, he devoted himself to creating conditions in which all those in the laboratory could develop their work fully, and with enjoyment. His clean, spare figure and somewhat austere expression betokened a firm directness and integrity which earned respect. Yet his quick, almost boyish, smile brought immediate realization that even his most devastatingly frank comments were made with kindness and human feeling. The trust that everyone gave him was never betrayed, and the 'Langie' that he was called behind his back was a term of genuine affection.

A. T. WELFORD

\section{Mr. S. Hazzledine Warren}

THE science of geology in Britain has always owed much to a strong body of highly competent amateurs. This applies particularly to the field of Quaternary geology, where the interests of the archæologist and geologist so usefully meet and interact. Like the late Arthur Bulleid, discoverer of the Glestonbury and Meare lake villages, Samuel Hazzledine Warren, who died on March 27 at the age of eighty-five, was first and foremost a geologist; and although he achieved remarkable distinction in the field of archæology, he did so very largely by applying the precise and cautious methods of the geological scientist.

He received no specific university training for either archæology or geology, and indeed began life as a business man; but he found this so little to his taste that he deliberately gave it up in favour of a life of patient and rewarding investigation. Thus he spent sixty happy years of research, a large part of them gladdened by the companionship of his wife who accompanied him, in his elaborately fitted expedition car, with his dog 'Silex'.

He concentrated the greater part of his research in south-east England, that sensitive region upon the margin of the maximal advances of two glaciations, and rich indeed were his rewards. His name is particularly associated with investigation of the inter glacial deposits at Clacton-on-Sea, where he established the presence of a Palæolithic industry of flint flakes and chopper-cores since widely recognized in other parts of the world. It was typical that he took great trouble to secure careful identification of the rich flora and fauna by reference to suiteble experts, and equally typical that when, thirty years later, the techniques of pollen analysis had been developed, he lost no time in securing that technique to supplement 